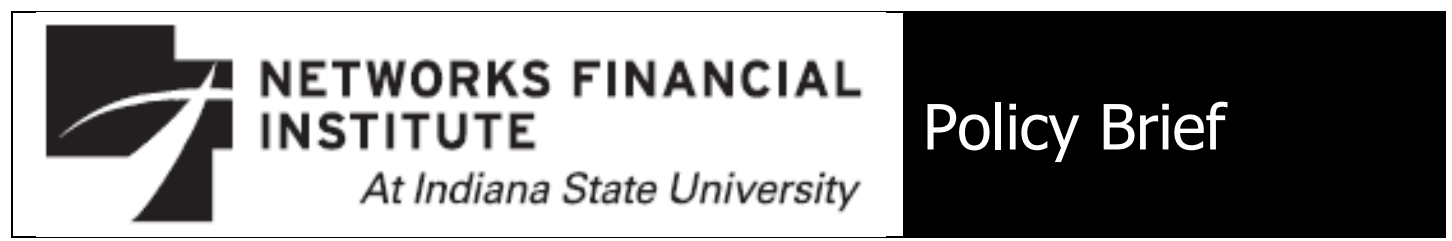

2011-PB-04

April 2011

\title{
Systemic Risks and Macroprudential Bank Regulation: A Critical Appraisal David VanHoose
}

Abstract: This paper discusses and critically appraises recent developments in the definition, measurement, and regulation of systemic risks. Although the issue of systemic risks has been subjected to considerable study, there is not widespread agreement on how to define this concept. Initial efforts to measure systemic risks emphasized aggregate financial ratios, and only recently have a variety of institution-level systemic-risk measurement techniques been proposed. Thus, regulators charged with conducting macroprudential regulation, such as the Financial Stability Oversight Council created by the Dodd-Frank Wall Street Reform and Consumer Protection Act, must act without a consensus about how to define and measure the form of risk they are charged with limiting. There are largely unexplored pitfalls associated with establishing a macroprudential-supervision apparatus: (1) An enlarged potential for regulatory capture and associated welfare losses; (2) A danger of over-relying on centralized governmental command-and-control mechanisms that might be at least as subject to breakdowns as private markets while under-relying on private market discipline; and (3) Failures to contemplate a role for private contractual (Coasian) solutions to externality problems that contribute to systemic-risk problems and to recognize that a broadened scope of regulations can actually undermine the incentives for financial institutions to contain these externality problems.

About the Author: David VanHoose earned his Ph.D. at the University of North Carolina at Chapel Hill and is currently the Herman W. Lay Professor of Private Enterprise at the Hankamer School of Business at Baylor University. Most recently, his work has appeared in Oxford Economic Papers, the Journal of International Money and Finance, and the European Journal of Political Economy. VanHoose served as a Visiting Economist at the Board of Governors of the Federal Reserve System in 1988 and as a Visiting Scholar at the Federal Reserve Bank of Kansas City in 1989. In 1991, he received the Iddo Sarnat Award for the outstanding article in the Journal of Banking and Finance, and in 1995 and 2000 he received the Atlantic Economic Journal's best article award. He is an editor of the Journal of Economics and Business and served on the editorial boards of Open Economies Review and the Atlantic Economic Journal. VanHoose is also the author of E-Commerce Economics, co-author (with Roger Leroy Miller) of Macroeconomics:Theories, Policies, and International Applications and Money, Banking and Financial Markets, and co-author of International Monetary and Financial Economics and Global Economic Issues and Policies.

Keywords: Systemic risk, macroprudential regulation.

JEL Classification: G28.

The views expressed are those of the individual author and do not necessarily reflect official positions of Networks Financial Institute. Please address questions regarding content to David VanHoose at

David_VanHoose@baylor.edu. Any errors or omissions are the responsibility of the author. NFI policy briefs and other publications are available on NFI's website (www.networksfinancialinstitute.org). Click "Thought Leadership" and then "Publications/Papers." 


\section{Systemic Risks and Macroprudential Bank Regulation: A Critical Appraisal David VanHoose}

\section{Introduction}

The U.S. Congress enacted the Dodd-Frank Wall Street Reform and Consumer Protection Act of 2010 in the wake of the Panic of 2008 and clearly with an eye to at least some recommendations offered by academic economists [see, for instance, Alexander et al (2006), Acharya and Richardson (2009), French et al (2010), Feldman and Stern (2010), and Dewatripont, Rochet and Tirole (2010)]. This law created a Financial Stability Oversight Council (FSOC) to "make recommendations to the [Federal Reserve's] Board of Governors concerning the establishment and refinement of prudential standards and reporting requirements...[i]n order to prevent or mitigate risks to the financial stability of the United States that could arise from the material financial distress or failure of large, interconnected financial institutions." ${ }^{1}$ Supermajority votes of the FSOC can designate certain firms as "systemically important" or to grant the Federal Reserve authority to require firms to divest assets to avert a "grave threat" to U.S. financial stability. The law also charges the FSOC with resolving disagreements among member agencies, collecting information for monitoring potential risks to the overall U.S. financial system, and

\footnotetext{
${ }^{1}$ The FSOC's ten voting members include the U.S. Secretary of the Treasury, the Chair of the Federal Reserve's Board of Governors, the Comptroller of the Currency, the Chair of the Federal Deposit Insurance Corporation, the Chair of the Securities and Exchange Commission, the Chair of the Commodity Futures Trading Commission, the Chair of the National Credit Union Administration, the Director of the Federal Housing Finance Agency, the Director of the Bureau of Consumer Financial Protection, and a Senateconfirmed independent member with insurance expertise. As of the date of this writing, the FSOC has convened only a handful of meetings characterized by inter-agency squabbling [see Borak and Hopkins (2010) and Hopkins (2010)], has issued reports offering few specifics [see Hopkins and Borak (2011)], and has had its agenda set primarily by Treasury and Federal Reserve officials, in part because of unfilled vacancies at heads of several other agencies [see Rehm (2011)].
} 
identifying threats to financial stability.

This feature of the Dodd-Frank Act has established the first effort in U.S. history to identify, measure, regulate systemic risks generated by activities of financial and nonfinancial firms, and the FSOC is the nation's first body charged with macroprudential regulation, or regulation focused on the banking and financial system as a whole as well as on the performance of individual institutions. What are systemic risks, and how might they be measured? How might macroprudential regulation and supervision be implemented within the banking industry? ${ }^{2}$ Why might there be potential pitfalls associated with the establishment of a macroprudential regulation superstructure? These are the key questions addressed in this policy brief. The next section focuses on issues related to the definition and measurement of systemic risks and to the execution of systemic risk. Section 3 evaluates potential difficulties that adoption of a macroprudential-regulation regime might generate. Section 4 provides a summary of the main conclusions.

\section{Defining, Measuring, and Regulating Systemic Risks}

There is nothing novel about the concept of systemic risk, which has occupied the attention of central banks, bank regulators, and financial economists for more than four decades. What is new is governmental interest in explicit regulation of systemic risks - even though old issues relating to defining and measuring systemic risks remain not completely resolved.

\subsection{The Slippery Concept of Systemic Risks}

2 For analysis of systemic risks within the insurance industry, see Grace (2010) and Acharya, Biggs, et al (2011). King and Maier (2009) and Brown, Lynch and Petajisto (2011) examine systemic risk regulation of hedge funds and mutual funds. 
Table 1 provides quotations offering various definitions of systemic risk taken from a variety of sources. With the exceptions of Hendricks (National Research Council, 2006) and Kane (2010b) - discussed in greater detail in Section 3-the alternative definitions mainly tend to coalesce around two traditional notions of systemic risk discussed by Furfine (2003). The first type of systemic risk that Furfine identifies is "the risk that some financial shock causes a set of markets or institutions to simultaneously fail to function efficiently." He associates this definition with theoretical bankrun models such as that of Diamond and Dybvig (1983), who provide a rationale for bank runs as breakdowns in optimal risk-sharing arrangements caused by a generalized collapse of depositor confidence. Wicker (1996, p. 162) refers to this as the "random withdrawal" approach to modeling bank runs, which he associates with "illiquidity induced by a contagion of fear" which Calomiris (2010) calls the "panic view" - and contrasts with asymmetric-information theories of rational, information-based bank runswhich Calomiris terms the "fundamentalist view." Of course, as Wicker (1996, p. 162) notes, distinguishing between these alternative perspectives on causes of generalized collapses "does not preclude that both may be at work simultaneously."

\section{Table 1}

Source

\begin{tabular}{|l|l|}
\hline Viral Acharya (2009, p. 224) & $\begin{array}{l}\text { "A financial crisis is 'systemic' in nature if many banks } \\
\text { fail together, or if one bank's failure propagates as a } \\
\text { contagion causing the failure of many banks," so } \\
\text { systemic risk "is modeled as the endogenously chosen } \\
\text { correlation of returns on assets held by banks." }\end{array}$ \\
\hline Bank of England (2009, p. 3) & $\begin{array}{l}\text { "Systemic risk has two principal sources. First, there is a } \\
\text { strong collective tendency for financial firms, as well as } \\
\text { companies and households, to overexpose themselves to } \\
\text { risk in the upswing of a credit cycle, and to become } \\
\text { overly risk-averse in a downswing. This has a variety of } \\
\text { underlying causes, including a perception that some }\end{array}$ \\
\hline
\end{tabular}




\begin{tabular}{|c|c|}
\hline & $\begin{array}{l}\text { financial institutions may be too important to fail and } \\
\text { herding in markets. Second, individual banks typically } \\
\text { fail to take into account the spillover effects of their } \\
\text { actions on the rest of the financial network." }\end{array}$ \\
\hline Claudio Borio (2003, pp. 5-7) & $\begin{array}{l}\text { "The commonly held view of systemic risk...tends to see } \\
\text { widespread financial distress as arising primarily from } \\
\text { the failure of individual institutions..., to treat risk as } \\
\text { endogenous in terms of the amplification mechanisms but } \\
\text { not with respect to the original shock, which is seen as } \\
\text { exogenous,... [and] this goes hand in hand with a rather } \\
\text { static view of instability. [Under a broader } \\
\text { view],...systemic risk arises primarily through common } \\
\text { exposures to macroeconomic risk factors across } \\
\text { institutions[, which] carries the more significant and } \\
\text { longer-lasting real costs... [and]...underlies most of the } \\
\text { major crises around the globe." }\end{array}$ \\
\hline $\begin{array}{l}\text { Monica Billio, Mila } \\
\text { Getmansky, Andrew Lo, and } \\
\text { Loriana Pelizzon (2010, p. 1) }\end{array}$ & $\begin{array}{l}\text { "Systemic risk can be realized as a series of correlated } \\
\text { defaults among financial institutions, occurring over a } \\
\text { short time span and triggering a withdrawal of liquidity } \\
\text { and widespread loss of confidence in the financial system } \\
\text { as a whole." }\end{array}$ \\
\hline $\begin{array}{l}\text { Markus Brunnermeier, } \\
\text { Andrew Crockett, Charles } \\
\text { Goodhart, Avinash Persaud, } \\
\text { and Hyun Shin (2009, p. xvii } \\
\text { and p. 2) }\end{array}$ & $\begin{array}{l}\text { [A situation in which] "...there are sufficient externalities } \\
\text { that the social, and overall, costs of market failure exceed } \\
\text { both the private costs of failure and the extra costs of } \\
\text { regulation" }\end{array}$ \\
\hline $\begin{array}{l}\text { Joseph Daniels and David } \\
\text { VanHoose }(2005, \text { p. } 196)\end{array}$ & $\begin{array}{l}\text { "...the risk that some payment intermediaries may not } \\
\text { be able to meet the terms of payment agreements because } \\
\text { of failures by other institutions to settle transactions that } \\
\text { otherwise are not related." }\end{array}$ \\
\hline $\begin{array}{l}\text { Olivier De Bandt Philipp } \\
\text { Hartmann, and José Luis } \\
\text { Peydró (2010, p. 636) }\end{array}$ & $\begin{array}{l}\text { "...the risk of experiencing systemic events in the strong } \\
\text { sense [, where a] systemic event in the narrow sense } \\
\text { entails an event...about a financial institution...leads to } \\
\text { considerable adverse effects on one or several other } \\
\text { financial institutions or markets... [and] in the broad } \\
\text { sense also [have] simultaneous adverse effects on a large } \\
\text { number of institutions or markets... [and where an event } \\
\text { is] strong...if financial institutions actually fail as a } \\
\text { consequence of the initial shock, although they have been } \\
\text { fundamentally solvent ex ante." }\end{array}$ \\
\hline Craig Furfine (2003, p. 113) & $\begin{array}{l}\text { "The first type [of systemic risk] is the risk that some } \\
\text { financial shock causes a set of markets or institutions to } \\
\text { simultaneously fail to function efficiently. The second } \\
\text { type...is the risk that failure of one or a small number of } \\
\text { institutions will be transmitted to others due to explicit } \\
\text { financial linkages across institutions." }\end{array}$ \\
\hline Group of $10(2001)$ & $\begin{array}{l}\text { "...the risk that an event will trigger a loss of economic } \\
\text { value or confidence in, and attendant increases in } \\
\text { uncertainty about, a substantial portion of the financial } \\
\text { system that is serious enough to quite probably have } \\
\text { significant adverse effects on the real economy." }\end{array}$ \\
\hline $\begin{array}{l}\text { Darryll Hendricks (National } \\
\text { Research Council, 2006, p. 9) }\end{array}$ & $\begin{array}{l}\text { Comparable to the Loch Ness monster, in that "...people } \\
\text { claim that it exists or must exist, but nobody can point to }\end{array}$ \\
\hline
\end{tabular}




\begin{tabular}{|c|c|}
\hline & a definitive episode." \\
\hline $\begin{array}{l}\text { Charles Lucas (National } \\
\text { Research Council, 2006, pp. } 2 \\
\text { and 9) }\end{array}$ & $\begin{array}{l}\text { Involves a "...transition from a stable equilibrium to } \\
\text { some inferior but stable equilibrium" involving a } \\
\text { sympathetic sequence of events - contagion' - that can } \\
\text { involve policy missteps and a feedback loop between the } \\
\text { financial and real sectors. }\end{array}$ \\
\hline Edward Kane (2010b, p. 253) & $\begin{array}{l}\text { "The primary characteristic of systemic risk is the } \\
\text { emergence of widespread concerns about the potential for } \\
\text { substantial 'spillovers' of contagious defaults across } \\
\text { counterparties in the financial sector and from these } \\
\text { defaults to breakdowns in the real economy. } \\
\text { This potential is traced either to individual firms' } \\
\text { overexposure to common risk factors } \\
\text { (underdiversification) or to a nexus of derivative } \\
\text { contracts that result in an unobservable web of debt that } \\
\text { highly leveraged institutions owe to one other } \\
\text { (contagion). } \\
\text { These concerns cannot be the only symptom } \\
\text { because, with the notable exception of the Lehman } \\
\text { bankruptcy, in modern crises substantial spillovers of } \\
\text { action defaults have remained largely hypothetical. In } \\
\text { country after country and sector after sector, monetary } \\
\text { and fiscal authorities instinctively choose to intervene in } \\
\text { the default process by supporting the credit of } \\
\text { 'systemically important' institutions that allow } \\
\text { themselves to become economically insolvent. } \\
\text {... The existence of this verifiable additional } \\
\text { symptom suggests that an authentic definition of } \\
\text { systemic risk ought to focus on a firm's or sector's ability } \\
\text { to command or extract implicit or explicit life support } \\
\text { from national safety nets. }\end{array}$ \\
\hline $\begin{array}{l}\text { Jan-Charles Rochet and Jean } \\
\text { Tirole (1996, p. 733) }\end{array}$ & $\begin{array}{l}\text { "The propagation of an agent's economic distress to other } \\
\text { agents linked to that agent through financial } \\
\text { transactions." }\end{array}$ \\
\hline Jeremy Staum (2010, p. 2) & $\begin{array}{l}\text { "...involves risk that arises because of the structure of the } \\
\text { financial system and interactions between financial } \\
\text { institutions. Systemic risk is not the same as systematic } \\
\text { risk, which is risk explained by factors that influence the } \\
\text { economy as a whole. Systemic risk includes systematic } \\
\text { risk and also risks arising from phenomena such as } \\
\text { contagion, the transmission of losses or distress from one } \\
\text { institution to another." }\end{array}$ \\
\hline
\end{tabular}

One commonality of both perspectives on the generalized-collapse notion is an emphasis on demand-side sources of systemic risks emanating from proactive decisions by bank depositors that generate essentially passive responses - such as suspensions of convertibility of deposits or 
failure-on the part of banks that are essentially captives to runs. Another commonality is the idea that systemic risks affect multiple institutions simultaneously, suggesting correlated asset strategies, or "herding behavior," which makes them susceptible to runs by depositors [see, for instance, recent analyses of incentives for bank herding by Acharya and Yorulmazer $(2007,2008)]$.

In the past, central bankers have given greater attention to the second traditional view of systemic risk identified by Furfine, which is "the risk that failure of one or a small number of institutions will be transmitted to others due to explicit financial linkages across institutions." This perspective on systemic risk emphasizes supply-side channels of immediate interest to central banks concerned with the functioning of interbank clearings of daily transactions arising from interbank loans, securities exchanges, and foreign currency transfers. Visualizing systemic risk as the potential for a domino effect running across banks connected by clearing or other business linkages also accords with standard textbook definitions, such as the DanielsVanHoose (2005, p. 196) definition in Table 1: “The risk that some payment intermediaries may not be able to meet the terms of payment agreements because of failures by other institutions to settle transactions that otherwise are not related." For instance, failure of a transaction to settle between two banks can result in a third bank failing to receive a promised payment from one of the first two banks, which in turn can generate settlement failures down a line of institutions. Thus, this second notion of systemic risk views banks as the parties making conscious decisions to establish systemic linkages that, in the event of settlement breakdowns among a subset of institutions, can spill over to adversely affect banks' customers, which, ex post, are passive, essentially captive agents. 
Whichever of the two traditional views on systemic risk that one chooses as more appealing, there are three key private-market-related factors that potentially contribute to systemic risk. The first of these is fractional reserve banking. Many institutions, including particularly depository institutions such as commercial banks, savings institutions, and credit unions, hold reserves that are less than the total amount of customer deposits and other relatively short-maturity liabilities, such as interbank borrowings. As a consequence, an individual institution is always potentially susceptible to a positive net outflow of funds arising from the institution's interactions with its depositors and other customers, thereby resulting in at least a temporary liquidity shortfall. This is, of course, the traditional explanation for why banks are susceptible to runs. After all, banks facing an exposure to risks of individual liquidity shortfalls potentially could find themselves confronting a collective shortfall in the event of a negative shock to aggregate liquidity - a shortfall that could set off a more widespread run on the part of depositors or other creditors, including other banks.

The second key private-market contributor is the potential for banks to engage in correlated strategies - or what financial market participants and other observers more commonly call herding behavior. When profit opportunities arise in particular lending or other financial markets, bank managers will simultaneously tend to seek to gain from those opportunities. In the event that unexpected negative events hit the markets in which those opportunities previously had appeared to be highly profitable, then the result can be a negative aggregate liquidity shock. In addition, Wagner $(2008,2010)$ argues that traditional diversification at the level of individual institutions does not necessarily reduce systemic risk, because multiple 
institutions tend to choose similar diversification strategies, thereby worsening herding problems.

The third private-market factor that gives rise to systemic risk is network externalities. In general, an externality exists in a market when a characteristic of the market product exerts spillover effects on individuals or firms not party to transactions in the marketplace. Negative market externalities, such as air pollution, arise when transactions in the market spill over to reduce the welfare of people who are not necessarily involved in those transactions. Positive market externalities can also arise, such as in markets for vaccines for communicable diseases. When more people receive vaccinations in this market, the result is a spillover benefit-a reduced likelihood of being exposed to diseases for people not participating in the vaccine market. A network externality arises when the magnitudes of the benefits or costs that people or firms receive or incur through their individual transactions in a market depend on how many others also engage in market transactions. For example, it is commonly argued that the market for credit cards is subject to a network externality, in that the value to an individual consumer of utilizing a particular credit card brand is greater when it is more widely used by other consumers and accepted by a larger number of retailers. An item subject to network externalities can experience market feedback, or a tendency to fall into favor, resulting in a bandwagon effect as the item's value rises as more and more people utilize it, or to fall out of favor, generating a reverse bandwagon effect as the item's value declines when additional people choose not to use it. ${ }^{3}$

In banking markets, network externalities and associated market

3 See Caballero and Simsek (2009) for an analysis of negative bandwagon effects in relation to systemic risks. 
feedback effects most obviously arise in the course of depository institutions' operations as payment intermediaries [see, for instance, Chakravorti (2000) and Eisenberg and Noe (2001)]. In fulfilling their payment-intermediation role, banking institutions participate in interlinked payment systems. As in credit card markets, transactions in these systems can be subject to bandwagon effects - hence giving rise to systemic risk. All payment transmissions between two parties are subject to liquidity risks the potential for delayed payment transfers - and credit risks - the potential for partial or complete default on a promised payment. If the realization of such a risk could spill over to affect other parties in a payment system - for instance if a payment-transfer delay or default results in delays or defaults for other parties not involved in the original transaction - then there is a potential spillover, or systemic risk [see Wagner (2009) for a recent review].

Payment-system-related network externalities are particularly easy to visualize, but financial firms such as banks also experience network externalities in other contexts. For example, in interbank lending markets such as the federal funds market and derivatives markets, a default by one institution on a debt to another institution potentially can impinge on the latter institution's capability to honor debts owed to other institutions. In principle, the result could be a cascade of failures to honor obligations, resulting in realizations of systemic risks in the market [see, for example, Cocco, Gomes and Martins (2009), Fecht and Grüner (2007), Bliss and Kaufman (2006), Iori, Jafarey and Padilla (2006), and Freixas, Parigi and Rachet (2000)].

\subsection{Alternative Approaches to Measuring Systemic Risk}

Traditionally, economists have tended to rely on aggregate prudential ratios, such as aggregate capital ratios, to assess the overall 
financial system's safety and soundness. Such ratios are commonly used as well in the construction of possible early warning systems for banking and financial crises [see Barrell et al (2010) for a recent example and Davis and Karim (2008) and Evans et al (2000) for reviews]. Čihák and Schaeck (2010), however, document that even though such ratios sometimes have some informational content, they also suffer from some potentially significant difficulties. Among these difficulties with aggregate ratios are failures in identifying individual problem institutions and an over-reliance on backward-looking regulatory data instead of forward-looking market information.

Table 2 lists studies that have proposed ways of measuring systemic risk at the level of individual institutions or groups of institutions. As discussed by Gauthier, Lehar and Mouissi (2010), these proposed measures typically concentrate attention on the latter two private-market factors contributing to systemic risks. Hence, one category of studies seeking to measure systemic risk emphasizes correlated bank balance sheet strategies resulting in herding behavior and commonality of exposures to risks. Studies within this group often utilize stock capitalization data in an effort to measure correlations across institutions. Others estimate conditional probabilities of failure of one or more institutions conditioned on adverse economic events or on failure of other institutions. Some studies simply seek to identify common factors that are typically associated with significant or widespread institutional distress and, hence, consequently might serve as warning indicators of growing systemic risk exposures. 


\section{Table 2}

$\underline{\text { Study }}$

Systemic Risk Measure

\begin{tabular}{|c|c|}
\hline $\begin{array}{l}\text { Viral Acharya, Lasse Pedersen, } \\
\text { Thomas Philippon, and Matthew } \\
\text { Richardson }(2010,2011 \mathrm{c})\end{array}$ & $\begin{array}{l}\text { Systemic expected shortfall: An institution's } \\
\text { expected amount of undercapitalizatioin in } \\
\text { a future systemic event in which the system } \\
\text { as a whole is undercapitalized. } \\
\text { Marginal expected shortfall: An institution's } \\
\text { share of losses in the tail of the aggregate } \\
\text { sector's loss distribution, which is } \\
\text { measured as the average return of each } \\
\text { institution during the worst } 5 \text { percent of } \\
\text { worst days for the market as a whole. }\end{array}$ \\
\hline $\begin{array}{l}\text { Tobias Adrian and Markus } \\
\text { Brunnermeier (2009) }\end{array}$ & $\begin{array}{l}\text { CoVaR: The value at risk (VaR) of financial } \\
\text { institutions conditional on other } \\
\text { institutions being in distress. } \\
\text { Marginal contribution to systemic risk: The } \\
\text { difference between CoVaR and the } \\
\text { financial system's VaR. }\end{array}$ \\
\hline $\begin{array}{l}\text { David Aikman, Piergiorgio } \\
\text { Alessandri, Bruno Eklund, Prasanna } \\
\text { Gai, Sujit Kapadia, Elizabeth Martin, } \\
\text { Nada Mora, Gabriel Sterne, and } \\
\text { Matthew Willison (2009) }\end{array}$ & $\begin{array}{l}\text { Eight "danger zone" indicators: Simulated } \\
\text { effects on bank balance sheets of changes in } \\
\text { the expected future tier one capital ratio, } \\
\text { short-term wholesale maturity mismatch, } \\
\text { market funds reliance, past profitability } \\
\text { less unanticipated shock, similarity to } \\
\text { troubled bank, market interbank spread, } \\
\text { equity market drop, and past gross } \\
\text { domestic product. }\end{array}$ \\
\hline $\begin{array}{l}\text { Kee-Hong Bae, G. Andrew Karolyi, } \\
\text { and René Stulz (2003) }\end{array}$ & $\begin{array}{l}\text { Measure of financial contagion: The fraction } \\
\text { of "exceedance events"-joint occurrences } \\
\text { of large absolute value returns derived } \\
\text { from a multilogistic regression-in a } \\
\text { particular region that is left unexplained by } \\
\text { its own covariates but that is explained by } \\
\text { exceedance events in another region. }\end{array}$ \\
\hline $\begin{array}{l}\text { Monica Billio, Mila Getmansky, } \\
\text { Andrew Lo, and Loriana Pelizzon } \\
\text { (2010) }\end{array}$ & $\begin{array}{l}\text { Illiquidity risk exposure: Autocorrelation } \\
\text { coefficients of monthly returns. } \\
\text { Increased commonality of asset returns: } \\
\text { Principal components analysis. } \\
\text { Sudden shocks: Regime-switching models. } \\
\text { Directions of relationships: Granger causality } \\
\text { tests. }\end{array}$ \\
\hline $\begin{array}{l}\text { Christian Brownlees and Robert } \\
\text { Engle (2010) }\end{array}$ & $\begin{array}{l}\text { Time-varying institution-level conditional } \\
\text { volatilities, market-index correlations, and } \\
\text { joint-tail indices of Acharya et al's (2010, } \\
2011 b) \text { marginal expected shortfall. }\end{array}$ \\
\hline $\begin{array}{l}\text { Olli Castrén and Ilja Kristian } \\
\text { Kavonius (2009) }\end{array}$ & $\begin{array}{l}\text { Bilateral balance-sheet exposures to } \\
\text { sectoral counterparty risks }\end{array}$ \\
\hline Olivier De Jonghe (2010) & $\begin{array}{l}\text { Tail beta: The probability of a substantial } \\
\text { decline in a bank's stock price conditional }\end{array}$ \\
\hline
\end{tabular}




\begin{tabular}{|c|c|}
\hline & $\begin{array}{l}\text { on the plummeting of the value of a } \\
\text { banking index. }\end{array}$ \\
\hline $\begin{array}{l}\text { Gianni De Nicolo and Myron Kwast } \\
\text { (2002) }\end{array}$ & $\begin{array}{l}\text { Dynamics of stock return correlations of } \\
\text { large, complex banking organizations. }\end{array}$ \\
\hline $\begin{array}{l}\text { Helmut Elsinger, Alfred Lehar, and } \\
\text { Martin Summer }(2006 a, b)\end{array}$ & $\begin{array}{l}\text { Incremental Value at Risk: An individual } \\
\text { institution's contribution to the overall } \\
\text { banking system's value at risk. } \\
\text { Conditional expected shortfall: The increase } \\
\text { in expected deposit insurance liability of } \\
\text { the banking system resulting from an } \\
\text { institution's failure }\end{array}$ \\
\hline $\begin{array}{l}\text { Céline Gauthier, Alfred Lehar, and } \\
\text { Moez Souissi (2010) }\end{array}$ & $\begin{array}{l}\text { Component Value at Risk: Beta of losses of } \\
\text { each bank with respect to the losses of a } \\
\text { portfolio of all banks; measure of marginal } \\
\text { effect of an increase in bank's size. } \\
\text { Incremental Value at Risk: Increase in } \\
\text { overall industry risk generated by adding } \\
\text { the institution to the system. }\end{array}$ \\
\hline $\begin{array}{l}\text { Xin Huang, Hao Zhou, and Haibin } \\
\text { Zhu, } 2010\end{array}$ & $\begin{array}{l}\text { Distress insurance premium: Marginal } \\
\text { contribution to total risk in the form of the } \\
\text { expected loss on an institutional sub- } \\
\text { portfolio conditional on a large loss for the } \\
\text { full systemic portfolio. }\end{array}$ \\
\hline $\begin{array}{l}\text { Xin Huang, Hao Zhou, and Haibin } \\
\text { Zhu (2009) }\end{array}$ & $\begin{array}{l}\text { Estimated insurance premium to protect } \\
\text { against losses based on default } \\
\text { probabilities of individual institutions } \\
\text { within an interrelated group and forecasts } \\
\text { of asset return correlations within the } \\
\text { group }\end{array}$ \\
\hline $\begin{array}{l}\text { Giulia Iori, Saqib Jafarey, and } \\
\text { Francisco Padilla (2006) }\end{array}$ & $\begin{array}{l}\text { Number of simulated failures per unit of } \\
\text { time }\end{array}$ \\
\hline $\begin{array}{l}\text { Philippe Jorion and Gaiyan Zhang } \\
\text { (2009) }\end{array}$ & $\begin{array}{l}\text { Abnormal equity returns and cumulative } \\
\text { abnormal returns of bankrupt firms and } \\
\text { creditors. }\end{array}$ \\
\hline Alfred Lehar (2005) & $\begin{array}{l}\text { Risk of a bank regulator's contingent } \\
\text { claims on banking assets derived from } \\
\text { correlations among bank asset portfolios }\end{array}$ \\
\hline $\begin{array}{l}\text { Miguel Segoviano and Charles } \\
\text { Goodhart (2009) }\end{array}$ & $\begin{array}{l}\text { Banking stability index indicating the } \\
\text { expected number of banks to become } \\
\text { distressed given that at least one bank has } \\
\text { become distressed. }\end{array}$ \\
\hline $\begin{array}{l}\text { Nikola Tarashev, Claudio Borio, and } \\
\text { Kostas Tsatsaronis (2010) }\end{array}$ & $\begin{array}{l}\text { Shapley-value distributions of value at } \\
\text { risk or expected shortfalls to attribute to } \\
\text { each institution the average of its marginal } \\
\text { contribution to the potential losses across } \\
\text { all institutions. }\end{array}$ \\
\hline Chen Zhou (2010) & $\begin{array}{l}\text { Conditional failure probability: Probability } \\
\text { of at least one more bank failure } \\
\text { conditional on failure of a given bank. } \\
\text { Systemic impact index: Expected number of } \\
\text { failures in the banking system conditional } \\
\text { on failure of a given bank. } \\
\text { Vulnerability index: Probability of a }\end{array}$ \\
\hline
\end{tabular}


The second category of studies, which includes Gauthier et al's (2010) own analysis, focuses on systemic risks that banking institutions incur through their interactions via payment clearing systems or interbank credit markets. Consequently, studies within this group emphasize measuring exposures to contagious spillover effects of shocks experienced by "systemically important" institutions onto other institutions via linkages arising within payment or credit networks.

A perusal of Table 2 indicates that researchers have proposed a wide range of measures of systemic risk and that many of these proposed measures have been developed only recently. Systemic risk measurement is clearly in its early stages of evaluation. Furthermore, most measures of systemic risks hinge on existing approaches to analysis of bank risks, such as value-at-risk modeling, in spite of the fact that a number of researchers, such as Daníelsson (2008) have suggested that such approaches to risk measurement commonly yield inconsistent conclusions.

\subsection{Macroprudential Regulation of Systemic Risk}

However systemic risks are defined or measured, policymakers have expressed a strong intent to reduce them [for example, Bernanke (2008)]. Combating systemic risks is not a new objective of regulators, however. For example, more than two decades ago, the Federal Reserve struggled with the issue of how to reduce systemic risks in interbank markets arising from daylight overdrafts by banks in U.S. large-value payment systems. ${ }^{4}$

${ }^{4}$ One among several reviews of this earlier systemic-risk issue is VanHoose and Sellon (1989). See also the discussion in Footnote 17. 
By nature, systemic risks arise from interactions among institutions, a fact that leads many observers to conclude that systemic risks cannot be addressed by traditional bank supervision and regulation. For instance, Wyplosz (2009) argues that traditional "microprudential regulation," which "concerns itself with the stability of individual institutions" and examines "responses of an individual bank to exogenous risks," thereby "does not incorporate endogenous risk" and "ignores the systemic importance of individual factors such as size, degree of leverage, and interconnectedness with the rest of the system."

Recognition of the potential for traditional supervisory and regulatory policies to miss the mark with regard to systemic risks, active discussion of macroprudential regulation was under way several years prior to the Panic of 2008 [a good example is Borio (2003)]. According to Hanson, Kashyap and Stein (2010), "[i]n the simplest terms, one can characterize the macroprudential approach to financial regulation ${ }^{5}$ as an effort to control the social costs associated with excessive balance-sheet shrinkage on the part of multiple financial institutions hit with a common shock" [emphasis in original].

If one accepts Borio's (2009) conclusion that macroprudential regulation is "an old idea whose time has come" [also see Davis and Karim (2009)], how might a macroprudential regulatory regime be implemented? The first step, of course, would be to identify the set of institutions upon which a macroprudential focus should be placed. Toward this end, Brunnermeier et al (2009) offer a typical proposal for how to accomplish this initial step. They suggest (pp. 25-26) that systemic-risk measures such as

\footnotetext{
${ }^{5}$ Clement (2010) traces the term "macroprudential" back to a 1979 meeting of the Cooke Committee, which was a forerunner to the Basel Committee on Banking Supervision, and to a 1979 report by a working committee chaired by Alexander Lamfalussy at the Bank for International Settlements.
} 
those summarized in Table 2 in the previous section can be applied objectively to classify institutions - not just banks but any "financial players" that are "subject to systemic risk" - into one of the following categories: (1) individually systemic institutions that are so large and interconnected that a national government would under circumstances regard them as too big to fail; (2) systemic-as-part-of-a-herd institutions that are individually small but tend to engage in highly correlated strategies; (3) non-systemic large and not highly levered institutions that tend to pursue generally uncorrelated strategies; and (4) tiny institutions that are too small to pose systemic risks and which also tend not to herd with other institutions. Brunnermeier et al suggest that macroprudential supervision and regulatory policies should be directed toward institutions that objective systemic-risk measures classify within the first two categories. They argue that institutions falling within the latter two groups should be subjected only to traditional micro-based supervision and regulation.

Thus, as shown in Figure 1, Brunnermeier et al effectively propose leaving in place for all regulated financial institutions micro-based policies directed toward individual institutions in isolation. Macroprudential regulation would supplement the traditional set of supervision-andregulation policies among the subset of institutions that systemic-risk measures identify either to be within the individually systemic or systemicas-part-of-a-herd categories. 


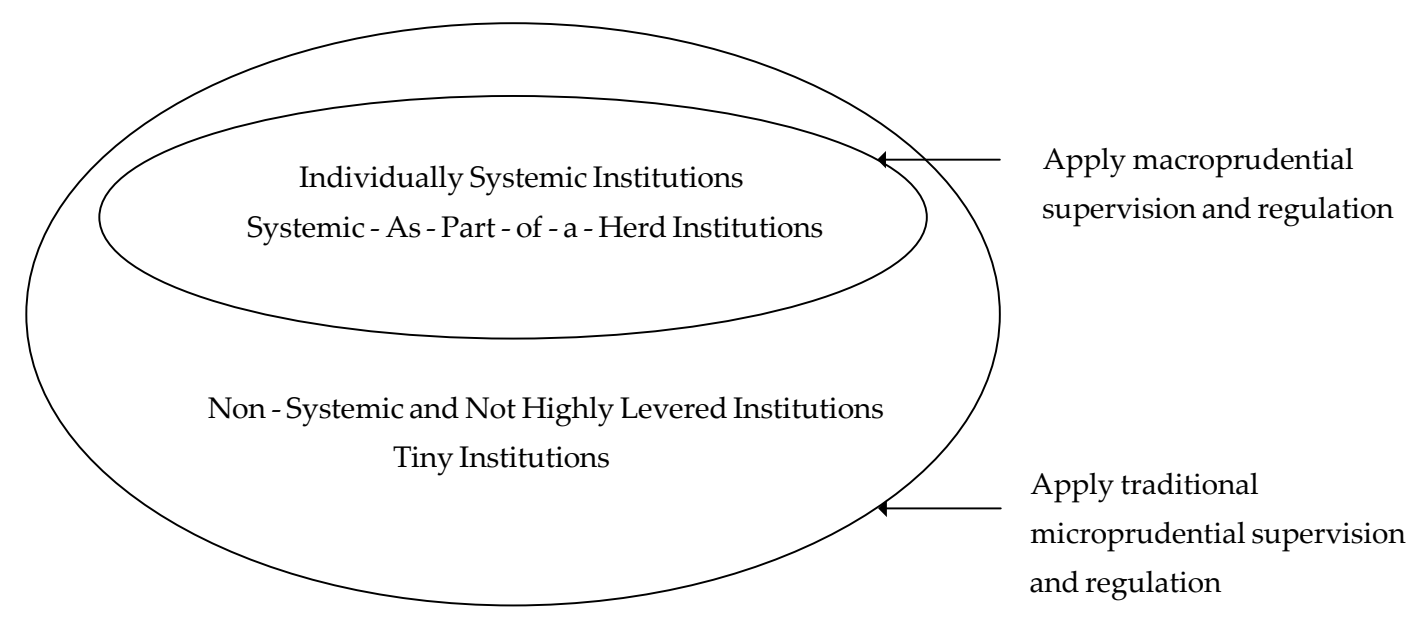

Figure 1: The Brunnermeier-Crockett-Goodhart Regulatory Scheme

The Dodd-Frank Act focuses primarily on the Brunnermeier et al's individually-systemic-institutions category but leaves open the possibility that a supermajority of the FSOC could broaden the list to include other groups of institutions. Nevertheless, to date the main exercises in counterfactual risk-assessment simulations conducted by regulators with systemic risks in mind [see Upper (2007) for a review]. These are the mediatermed "stress tests," which is known to U.S. regulators as the Supervisory Capital Assessment Program, focused attention on the largest U.S. banks [see Hirtle, Schuermann and Stiroh (2009)].

Because common shocks might arise in conjunction with cyclical economic and financial swings that influence the course of bank performance [see, for example, Albertazzi and Gambacorta (2009)], Persaud (2009) emphasizes the importance of a focus on establishing a system of macroprudential regulation that includes systems of automatic stabilizers. These might, he suggests, include upward and downward adjustments of capital adequacy regulations and liquidity buffer requirements during the course of business cycles. Persaud also recommends use of mark-to-funding 
accounting - in which market asset prices are used to value balance-sheet items for banks that rely on short-term funding, while present-value prices are utilized for these valuations for banks that rely on longer-term funding - and of regulations of bank management compensation aimed at focusing bank managers' decision-making away from immediate-run horizons [see VanHoose (2011) for a review of issues relating to regulation of bank management compensation].

Kashyap, Berner and Goodhart (2010) stress the importance of developing macroprudential regulatory rules and techniques for addressing the problem of "fire sales" that involve forced sales of typically relatively illiquid assets at prices dislocated from originally perceived fundamentals. ${ }^{6}$ Such fire sales, they argue, arise because banks face incentives -including a self-fulfilling drop in current prices of such assets when banks collectively encounter troubles - to gamble that they can avoid failure and postpone selling relatively illiquid assets. Consequently, banks will tend to try to sell these assets only when they are on the cusp of failure. Analysis of a generalequilibrium model leads Kashyap et al to conclude that the existence of multiple spillover effects from fire sales requires coordinated settings of multiple macroprudential policy tools, such as capital requirements, liquidity restrictions, and margin requirements.

Rochet (2010) argues that the current macroprudential emphasis on "systemically important institutions" is misplaced. In his view, macroprudential regulation should be focused on protecting platforms - in the language of the recent literature on two-sided markets, an intermediary

6 von Peter (2009) provides a theory of a linkage from a dynamic interplay between macroeconomic events and asset prices to banking and financial instability. Also see Caballero and Simsek (2009) as well as a survey of recent work on fire sales by Kashyap et al (2010). 
that brings together different groups of "end users," such as interbankcredit clearing systems and payment clearing mechanisms that service two sides of transaction-based two-sided financial markets. ${ }^{7}$ Specifically, Rochet (2010, p. 272-274) suggests that macroprudential regulators should "guarantee the integrity of a precise list of financial markets and infrastructures that are deemed 'vital': interbank...markets, money markets, and some derivative markets and large-value payment systems." Rochet proposes that these platforms "would only be directly accessible to a group of 'officially recognized financial institutions' that would have to comply with special regulatory requirements," which he proposes could be based on "market best practice[s] put in place by private central clearing platforms and would be directly supervised by the central bank" and that "the central bank would choose who belongs to the club and who does not." 8 Thus, Rochet would refocus macroprudential regulation onto clubs of government-selected institutions interacting on platforms with focuses circumscribed by supervisory authorities, an approach that he argues would, among other things, "eliminate the rationale for splitting or downsizing banks."

\footnotetext{
${ }^{7}$ See VanHoose (2009) for a review of two-sided payment markets and Rochet and Tirole (2006 and 2008) for detailed discussions of the role of the Coase theorem in defining twosided pricing structures.

${ }^{8}$ Of course, once a government regulator decides which institutions may or may not be part of such a "platform club," that group would no longer constitute a club as typically defined by public economists: namely, a voluntary organization of agents deriving benefits from jointly participating in production activities from which that organization may exclude others or from sharing in consumption of a good offering benefit streams from which the organization may exclude others. Once the highlighted word "voluntary" is deleted from the definition, a group in a platform would be transformed from a club into a restricted group of institutions chosen for regulation by a government agency or agencies.
} 


\section{Pitfalls of Macroprudential Regulation: A Public Choice Perspective}

There are several obvious difficulties associated with implementation of any macroprudential-supervision framework. For instance, White (2008) worries about problems with "acceptance" by national regulators, regulatory inertia in developing a will to act at the appropriate time, and conflicts with monetary policymaking. In addition, Born, Ehrmann and Fratzscher (2010) raise concerns about the use of speeches and interviews by macroprudential regulators, which they find in analysis of more than 1,000 speeches, interviews, and formal Financial Stability Reports (FSRs) for 36 nations, tend to add to financial instabilities, whereas FSR releases generally are associated with reduced instabilities.

It is arguable, however, that there are three deeper pitfalls that have yet to be fully investigated in the literature on systemic risks and macroprudential regulation. The first of these is the threat of an enhanced likelihood of regulatory capture and accompanying reductions in social welfare. Another is the danger of overreliance on perceived market failures to rationalize macroprudential regulation without due attention to governmental regulatory failings. Finally, most research on addressing prospective systemic-risk externalities jump to proposals for public solutions - such as macroprudential regulation - without contemplating either potential private contractual solutions or ways in which expanding the financial regulatory superstructure could contribute to externalities associated with systemic risks. Let's consider each of these issues in turn.

\subsection{Ignoring the Threat of Regulatory Capture}

The traditional rationale for macroprudential supervision and regulation is the promotion of the public interest via limitation of the effects 
of widespread externalities that can generate welfare-reducing market failures. Nevertheless, in a discussion of the general theory of regulation, Posner (1974) contends that "theoretical and empirical research...[has] demonstrated that regulation is not positively correlated with the presence of external economies..." Likewise, in their survey of general theories of regulation, Viscusi, Harrington and Vernon (2005, pp. 376-378) argue that "many industries have been regulated for which there is no efficiency rationale" and that "in many cases, firms supported or even lobbied for regulation."

The economic approach to the theory of regulation helps to explain Posner's and Viscusi et al's observations regarding problems with viewing regulation as necessarily being in the public interest. As pointed out by Posner (1971), governments may employ regulation as a means of transferring economic rents from one group to another in exchange for implicit or explicit rewards. As a limiting case, incumbent firms might even, as suggested by Stigler (1971) utilize a regulatory apparatus as a means of "capturing" supervisory officials possessing the power to generate higher rents by erecting barriers to competition from new entrants.

Applying this economic approach-reviewed most recently by Veljanovski (2010) - to macroprudential regulation indicates that government officials and even regulated financial institutions might promote establishment of another financial regulatory superstructure to enable the pursuit of self-interested goals. Alternatively, even if a publicinterest motivation for such a superstructure prevails, incentives to pursue self-interests ultimately could skew day-to-day supervision in favor of providing protections for regulated financial institutions. Indeed, in many instances it would be difficult to disentangle the motivations for certain 
policy actions. Consider, for instance, the United Kingdom's Financial Services Authority's efforts to seek authority to block hostile bank takeovers (see Horobin and Boschat, 2011). The FSA has indicated that it desires such authority on systemic-risk grounds. Nevertheless, negating takeovers also could have the effect of protecting entrenched managers of incumbent banks, an outcome consistent with the economic theory's prediction for the limiting case of a captured regulator.

Certainly, there is considerable evidence that more than just a public interest motivation explains the historical and contemporaneous patterns of banking regulation. For instance, Lown and Wood (2003) provide evidence suggesting that the banking industry has been able to induce regulators to set the industry's desired level of reserve requirements. In addition, Abrams and Settle (1993) conclude that banks managed to induce regulators to produce their preferred industry structure in the 1930s, and Kroszner and Strahan $(1999,2001)$ obtain an analogous conclusion for the deregulation period of the 1970s and 1980s.

Are financial regulators particularly susceptible to capture by regulated banks? Hardy (2006) examines the issue of bank regulatory capture in the context of criteria proposed by Laffont and Tirole (1991) and concludes that in light of the significant concentration of banking markets, the prevalence of informational asymmetries, and the inherent complexities complicating formation of perceptions by industry outsiders, conditions are inherently favorable for regulatory capture in the banking industry. Masciandaro and Quintyn (2008) present evidence from analysis of data from 88 nations that both a predisposition for concentrated banking markets and the consolidation of power within smaller sets of regulators increases the likelihood of regulatory capture. 
Boyer and Ponce (2010) provide a theoretical analysis suggesting that granting one self-interested regulator-such as the Federal Reservepreeminent position with respect to both traditional micro-based regulation and macroprudential regulation on a financial stability committee could increase the risk of industry capture of that regulator. This conclusion emerges in the context of a model in which the preeminent regulator's ability to gather all relevant information gives that regulator an informational advantage over other members of the financial stability committee. The preeminent regulator can then withhold information from the committee in exchange for "bribes" from the industry. In Boyer and Ponce's framework, splitting the functions of micro-based regulation and macro-prudential regulation between two supervisory agencies complicates industry efforts to prevent the financial stability committee from obtaining signals about the industry's risks, which ultimately enables the financial stability committee to obtain an overall clearer signal of industry risk at a lower effective overall "bribery cost." Indeed, Boyer and Ponce find that even in a hierarchical financial-stability-committee structure, with a microregulatory agency subservient to a macro-prudential agency, a better outcome for society can emerge than the single-agency case. Nevertheless, splitting micro-based and macro-prudential regulatory authority across at least two different regulators yields a socially preferred outcome. A multiregulator structure, Boyer and Ponce conclude, prevents that capture of a preeminent yet more readily captured regulator from degrading the signal of the industry's true risks. ${ }^{9}$

\footnotetext{
${ }^{9}$ One element not taken into account in Boyer and Ponce's analysis is the potential for competition among bank regulators in settings in which regulated institutions have the ability to choose among regulators by engaging in "charter flips." As shown by Weinberg (2002), in such an environment a crucial consideration is whether the consolidated budget
} 


\subsection{A Continuing Under-Reliance on Market Discipline and Confusion of Market Failures with Failures of Government Discretion}

The never-quite-fully-implemented Basel II system of bank supervision and regulation was said to be based on three pillars: capital requirements, supervisory review guidelines, and market discipline. As discussed in VanHoose (2007a), the latter two pillars, which covered only slightly more than 20 percent of the formal description of Basel II, actually amounted to codification of supervisory discretion by regulators and enunciation of a small handful of worthwhile objectives for market transparency but very little in the way of encouragement of either effective market monitoring by private investors or utilization of market signals by regulators. To date, official discussions of a new Basel III system have focused once more on capital requirements, which some research suggests have ambiguous implications for overall safety and soundness of the banking system. ${ }^{10}$ All in all, providing a true role for market discipline appears to have taken a back seat to discretionary government policies aimed at assuring increased safety and soundness.

In a review of the effects of the regulation of non-financial markets, Winston (2006, pp. 73-76) argues that "[m]arket failure is less common and less costly than might be expected because market forces tend to correct certain potential failures" and that "...in at least some instances market

constraint of each of the competing regulators does or does not include the provision of funding for the deposit insurance system.

10 See, for instance, studies surveyed by VanHoose (2007b) as well as Eichberger and Summer (2005) and Kupiec and Nickerson (2004). Empirical work by Jokipii and Milne (Forthcoming) and Delis, Tran and Tsionas (2009) indicates significant heterogeneities in risk responses of banks to capital regulation, including responses involving more rather than less risk taking by some institutions. Recent events, of course, revealed that adverse outcomes at only a few institutions can generate significant losses for taxpayers. 
participants have greater incentives to correct market failures than the government has to correct these failures." Winston concludes that government policies that have "created economic inefficiencies where significant market failures do not exist" or that have "achieved expensive successes...or in some cases ha[ve] actually reduced social welfare" have "cost the U.S. economy hundreds of billions of dollars a year."

In the case of regulatory policies within the sphere of banking and finance, traditional rationales offered for government efforts to combat systemic risk with macroprudential supervision and regulation rarely confront the potential for government policy failures. Between the middle of 2007 and early 2009, for instance, the Federal Reserve and other U.S. banking policymakers misdiagnosed a credit-quality/solvency crisis as a standalone liquidity crunch. As discussed by Eisenbeis (2010), discretionary policy actions that these authorities pursued consequently failed to address the underlying problem and allowed it to fester. Indeed, Thornton (2010) suggests that discretionary policy actions intended to broaden banks' access to liquidity actually worsened the meltdown by compounding market uncertainties regarding the health of credit counterparties.

Of course, the literature on rules versus discretion almost unanimously comes down in favor of rules [see, for instance, Mishkin (2006)]. In the long run, coupling policy discretion with time inconsistency problems yields biased policy outcomes. In the short run, discretion also can create counterproductive uncertainties. Duffie (2010, p. 60) suggests that

...the discretion held by a resolution authority to initiate a resolution process could raise uncertainty among creditors regarding the potential timing of any such initiative, and 
generate doubt over the treatment of their claims against the failing institution. Faced with such uncertainty, a run by creditors might be accelerated. [...A] bankruptcy approach, if well designed, is likely to offer less discretion, and thus be more predictable in its consequences for counterparties and creditors. This would lower the risk of a run.

Nevertheless, both past and recent experiences verify that regulators commonly opt for policy discretion based on sometimes overly rosy views of favorable outcomes for banks' market valuations in relation to the social costs of discretion [see Mailath and Mester (1994)]. Levine's (2010, p. 8) summary assessment is that "[i]n example after the example, the financial regulation authorities (i) were aware of the problems associated with their policies, (ii) had ample power to fix the problems, and (iii) chose not to."11

Although discretionary policy mistakes certainly can prove costly, fundamental errors in the design and implementation of regulatory superstructures provide a much larger scope for government policy failures to create substantial social expenses. The popular interpretation of the Panic of 2008 is that it was "caused" by the greed of Wall Street bankers. Greed certainly played a role in the meltdown, but greed is a prevailing feature of economic and financial upswings as well. Key incentives for the greed that contributed to the 2008 panic were provided by governmental financial and regulator policies put into place in advance of the crisis and maintained even in the face of a significant decline in credit quality and bank asset values. These included the implementation of the too-big-to-fail policy in the 1980s, which gave the nations' largest banks an incentive to become

11 Consider an account (Phillips, 2010) of the assessment provided by Anton Valukas, a court-appointed examiner of the unwinding of Lehman Brothers Holdings, Inc.: "Federal regulators knew about [Lehman's risks] but failed to act. 'I have no evidence that anyone at Lehman ever lied to the government about anything,' Mr. Valukas said. 'What the Lehman experience should show is the necessity for having...trip wires in place.'” 
sufficiently large to qualify; the decision by Congress to exempt nearly all banks from risk-based deposit insurance premiums after the deposit insurance fund was declared "sufficient" during the mid-1990s; the government's decision to provide "implicit" guarantees for the Federal National Mortgage Association (FNMA) and Federal Home Loan Mortgage Corporation (FHLMC) support of the residential mortgage market; and the failure of bank regulators to follow prompt corrective action guidelines specified by the FDIC Improvement Act of 1991 and hence neglecting to issue cease-and-desist orders, declining to close insolvent institutions, and via the Federal Reserve's "liquidity programs" - providing funds to a number of institutions that were already financial zombies. ${ }^{12}$

To the above list must be added the failure of the FDIC's Bank Insurance Fund to accumulate additional reserves during good times. As shown in Figure 2, the effective premium rate that the FDIC charged to commercial banks increased in the early 1990s after the FDIC received authority to charge risk-based premiums. Congress prohibited the FDIC from charging deposit insurance premiums to all but the riskiest institutions, however, if the deposit insurance fund exceeded an "adequate" threshold. Hence, the effective deposit insurance premium dropped to a level not significantly different from zero. For all intents and purposes,

\footnotetext{
12 Jones and Oshinsky (2009) provide evidence that the increased concentration of deposits among the largest U.S. depository institutions significantly raised risks to the FDIC's insurance fund. Theoretical work by Hakenes and Schnabel (2010a) suggests that widespread use of credit-risk-transfer mechanisms such as asset-backed securities issued by FNMA, FHLMC, and other agencies and institutions can induce reductions in the quality of credit extended by imperfectly competitive banks. Wagner and Marsh (2006) reach an analogous conclusion and argue that credit-risk transfers to non-banks promotes financial stability by transferring credit risks outside a more fragile banking sector-though events within the shadow banking sector prior to and during the Panic of 2008 cast some doubts on this argument.
} 
federal deposit insurance guarantees were "free" between the mid-1990s and the mid-2000s, so that the deposit insurance fund failed to grow during this interval. The highly procyclical pattern displayed in Figure 2 casts doubt on whether proposals for "liquidity insurance" modeled on deposit insurance schemes [see, for instance, Perotti and Suarez (2009)] would prove particularly helpful in addressing episodes in which substantial systemicrisk realizations occurred. ${ }^{13}$

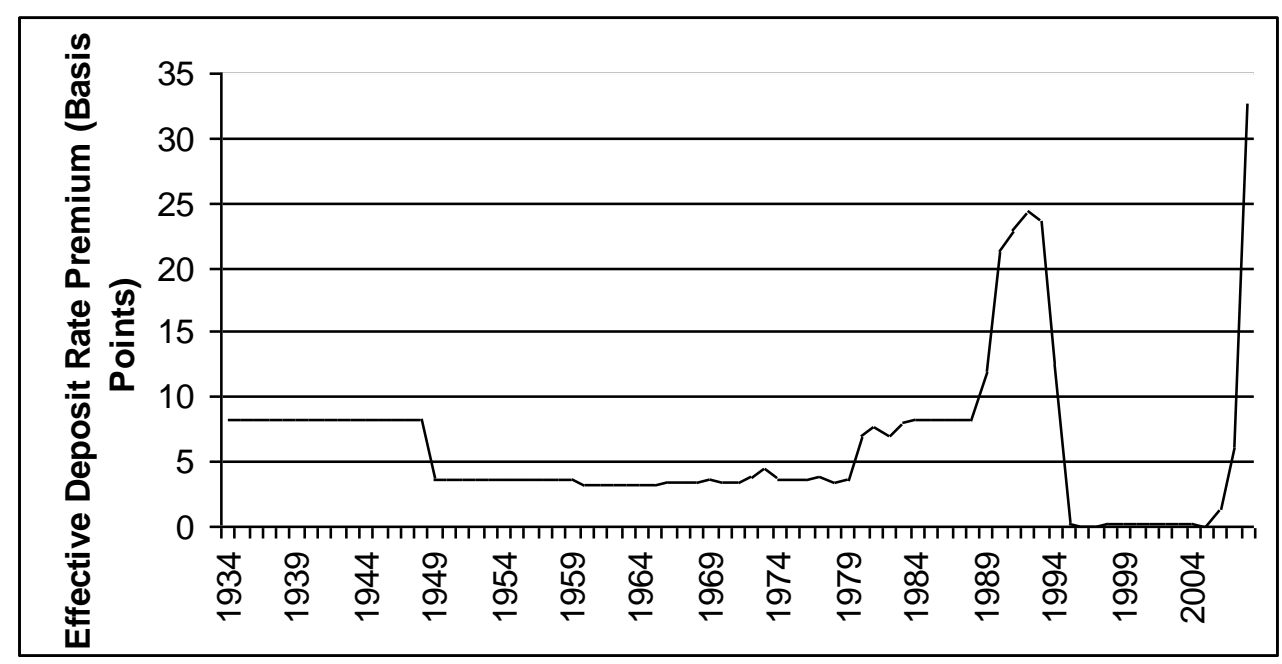

Figure 2: Effective FDIC Premium Rate for Deposit Insurance Sources: Kroszner-Melick (2008) and Federal Deposit Insurance Corporation

Figure 3 shows that in response to the various government incentives that were put into place following the mid-1980s, banks allocated a progressively larger percentage of their loans to real estate loans. The potential for a widespread systemic breakdown thereby grew steadily. During this period, many professors (such as this writer) undoubtedly pointed out to their classes the dangers of increasingly undiversified bank

\footnotetext{
${ }^{13}$ The FDIC's fund was wiped out in the aftermath of the Panic of 2008, and the substantial increase in the effective premium rate since that year that is displayed in Figure 2 reflects an ongoing effort to replenish the insurance fund.
} 
balance sheets. A very small handful even issued written predictions of an impending crash (see, for instance, Gilbreath, 2007-2008). Ultimately, the Panic of 2008 ensued.

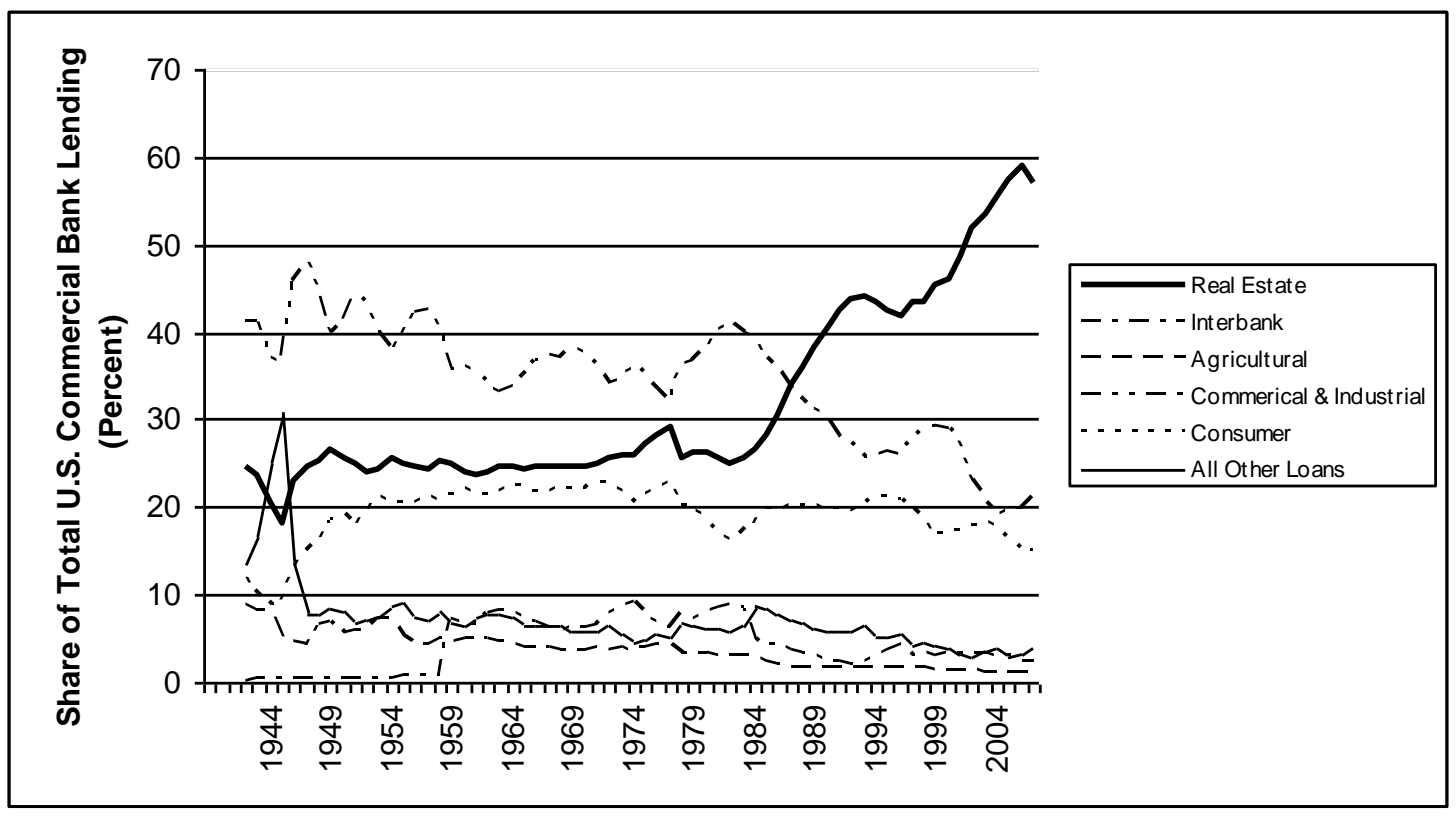

Figure 3: U.S. Commercial Banks' Loan Allocations

Source: Federal Deposit Insurance Corporation

It is unclear, though, whether a macroprudential regulator would have recognized the impending crisis - or if it had, whether it could have acted. After all, the incentives were created by laws of the land, including laws that continue to require regulators who are now members of the Financial Stability Oversight Council to enforce policies that contributed to the mid-2000s housing bubble. Indeed, one criterion that U.S. regulators take into account in their "safety-and-soundness" supervision of banks is the extent to which banks extend credit to lower-income households such as those whose deteriorating-quality subprime loans contributed to the Panic of 2008 .

What is clear is that the macroprudential-regulatory structures that 
have been proposed and that are being put into place promise to expand substantially the role of government oversight - buttressed by the potential for continued government bailouts - at the expense of private market discipline. Of course, there has long been a trend in this direction, in spite of the Basel II framers' claim of market discipline as a regulatory pillar.

This fact, which helps to explain Kane's (2010b) idiosyncratic definition of systemic risk included in Table 1, suggests the potential for a continued expansion of moral hazard risks that can widen exposures to systemic risks. Kane continues as follows:

Government officials everywhere acknowledge a responsibility for overseeing systemic risk. But before one can begin to control a target variable...one must define the variable comprehensively and fashion from this definition one or more verifiable metrics for monitoring the target.

Official definitions of systemic risk fail both of these tests. Official definitions focus on a perceived potential for substantial spillovers of institutional defaults across important firms in the financial sector and from this sector to the real economy. These definitions are not comprehensive because they exclude a systemic phenomenon: that substantial spillovers of actual defaults have remained largely and predictably hypothetical.

...It is no accident that the official diagnosis of the securitization bubble and the treatment plan it supports do not address the endogenous role that safety-net subsidies play in incentivizing firms to operate outside the boundaries of the regulatory system and to take political and economic action to attain and strengthen [...difficult-to-fail-and-unwind] status. Authorities do not wish to acknowledge that principled efforts to define and pursue the public interest are contested and repeatedly knocked off course by conflicting personal, bureaucratic, and political concerns that impinge inappropriately on government decision makers (Kane, 2010b, pp. 251-252).

Thus, Kane perceives systemic risk as fundamentally intertwined 
with the magnitudes of government guarantees. His analysis suggests an endogeneity between systemic exposures and safety-net subsidies not taken into account in the bulk of proposals for, evaluations of, and establishments of macroprudential-regulation authorities. A direct consequence, Kane (2010a, pp. 3 and 5) argues, is that, "[d]espite its length, the [Dodd-Frank] Act... offers numerous opportunities for the regulatory community to misread its authority or otherwise miss its marks[,...as] authorities are cycling between the stages of denial and superficial political bargaining."

Hakenes and Schnabel (2010b) offer a different rationale for how safety-net actions by governments can expand the scope of systemic risk. These researchers provide a theoretical analysis suggesting that the actual extension of bailout funding to a subset of threatened institutions can boost the risks of the bailed-out institutions' competitors. The reason is that receiving bailouts gives the recipient institutions an incentive to expand their operations, which increases competition in banking markets, thereby intensifying pressures on competing institutions to take on greater risks - some of which can add to systemic pressures.

\subsection{Public versus Private Solutions to Externality Problems, Regulation- Obscured Property Rights, and Increased Private Transaction Costs}

Recent authors have proposed that governments and regulators should seek to combat systemic risks in the financial sector using public-sector tools often advocated for addressing negative externalities in non-financial markets. Negative externalities arise when participants in a market do not have an incentive to take into 
account the spillover costs that their activities create for others. As a consequence, there is a divergence between social marginal cost and private marginal cost - that is, a "marginal damage" [see, for instance, Hindriks and Myers (2006) and Rosen and Gayer (2010)] experienced by society at large. Other things being equal, the consequence of a continuing failure of market participants to internalize this marginal social damage generated by their private interactions must be a perpetuation of the resulting negative externality.

In principle, a central planner might seek to eliminate the marginal damage created by the mismatch between social and private marginal cost through the use of types of policy tools sometimes proposed for combating negative externalities such as air, noise, or water pollution. One such policy tool is a Pigouvian taxnamed for Arthur Cecil Pigou, a British economist of the late nineteenth and early twentieth centuries. A Pigouvian tax is set exactly equal to the value of the marginal damage. Imposing such a tax on sellers of a product subject to a negative externality would bring private marginal cost into alignment with social marginal cost and thereby induce sellers to reduce production, thereby alleviating the negative externality. Acharya et al (2011a) argue that a system of Pigouvian taxes imposed on financial firms likewise could mitigate negative externalities associated with systemic risks created by their activities. Such a system, they suggest, might include implicit taxation via appropriately risk-adjusted capital requirements, mandated issuance of special claims converting certain debts to equity in bad states of the world, windfall profits taxes imposed on 
financial institutions during good times, or double-liability rules for these institutions' shareholders.

Another tool for addressing a negative externality such as pollution is a cap-and-trade policy, in which a central planner determines a socially optimal level of pollution, creates licenses to engage fixed levels of pollution-generating activities, and allows producers to trade these licenses. The market price of these licenses should reflect the underlying marginal damage of the firms' activities, so paying for these licenses would thereby internalize this marginal damage and bring private marginal cost into line with social marginal cost. Milne (2010) proposes extending such a capand-trade system to financial firms by identifying an optimal level of measurable systemic risk that governments will permit and then tradable issuing licenses for financial firms to contribute fixed shares of this aggregate permitted systemic-risk level.

Proposals such as these reflect what de la Torre and Ize (2011) call a "collective action perspective" on systemic-risk regulation centered on command and control based on governmental central planning. ${ }^{14}$ This perspective abstracts, of course, from consideration of implications of the analysis of Coase (1960), which examines how private contracting potentially can eliminate market externalities without discretionary government involvement but rather under a system of government-enforced rules regulating private interactions. Coase's conclusion, commonly known as the "Coase theorem," is that in a competitive economy with legally enforced property rights,

${ }^{14}$ For example, Majnoni (2010, p. 7) views governmental "financial supervisors" as being "in control of...financial intermediation activity" [emphasis added]. 
complete information, and zero transaction costs, resources will be allocated efficiently - meaning that there will be no misalignment of private and social marginal costs. Coase argued that in such a setting, if victims of a negative externality own legally enforceable property rights subjected to spillover damage by producers, they will be willing to sell producers the right to create such spillovers as long as producers provide compensation, which brings private marginal cost into line with social marginal cost. In contrast, if producers own the property rights, then victims of spillover costs would be willing to pay an amount equal to the resulting marginal damage to producers to induce them to cut their output back to the socially efficient level.

The Coase theorem suggests that internalization of costs via private contracting is most feasible when markets are competitive, private property rights are clearly defined, informational asymmetries are minimal, and transactions costs are low. Hence, Coase's argument suggests that the primary responsibilities of a government aiming to achieve social optimality are to promote market competition, encourage transparency on the part of all market participants, establish crystal clarity of private property rights, and avoid establishing rules that raise transactions costs faced by private parties. Thus, the Coase theorem's implication for most current macroprudential proposals or superstructures is that regulatory rules that inhibit competition among financial institutions, that fail to promote transparency by financial institutions, that make property rights more obscure, and that establish multiple layers of procedural obligations for financial institutions and their counterparties hinder 
the internalization of externalities that they encounter in financial markets.

Discussions of Coasian implications for financial markets have arisen most recently primarily in specific narrow contexts, such as analysis of pricing structures in two-sided payment systems. ${ }^{15}$ There has been no discussion of the Coase theorem, however, in the bulk of the recent literature on systemic risk and macroprudential regulation. In light of the fact that externalities relating to systemic risk lie at the heart of rationales for macroprudential regulation, this is a curious oversight.

What accounts for the absence of any consideration of a Coasian perspective in contributions to the literature on macroprudential regulation? Presumably proponents of macroprudential regulation who abstract from Coasian considerations presume that Coasian solutions to systemic-riskrelated externalities are infeasible and hence can be ruled out ex ante. Whether such a presumption is warranted, however, is highly debatable. After all, activities in financial markets involve the exchange of private contracts. As long as rules requiring transparency are enforced, market values to these contracts for possible states of the world can be determined and hence accrue to the owners of the property rights assigned to the financial contracts. ${ }^{16}$

\footnotetext{
${ }^{15}$ See Footnote 7.

${ }^{16}$ Levine (2010) proposes creating a "Sentinel" charged primarily with ensuring collection and public dissemination of information about both financial markets and the state of financial regulation and its governance. Analogously, Pollock (2010) suggests creating a "systemic risk advisor" to monitor and report rather than trying to placing existing bank supervisors in charge of trying to limit systemic risk directly. Consistent with the thrust of these proposals, Schotter and Yorulmazer (2009) report evidence from an experimental study indicating that availability of information significantly affects the severity of banking
} 
If public policy promotes minimized financial-market entry barriers and transaction costs, these market values should be consistent with the attainment of allocative and technical efficiency.

Undoubtedly, the key rationale that most macroprudentialsupervision proponents would offer for ruling out Coasian considerations is based on the argument advanced by Diamond and Dybvig (1983), the well-known and influential study that first motivated a bank run as an equilibrium phenomenon arising from an externality arising from the conjunction of intertemporal consumption uncertainty and a fixed sequential system - first-come, first-served-governing bank payouts of funds to depositors. Diamond and Dybvig demonstrated within the context of their model that private contracts could not prevent socially undesirable runs, which they suggested could be prevented only via establishment of a credible guarantee of full payment to depositors by an outside agent such as a government deposit insurer.

There are three fundamental difficulties with DiamondDybvig's anti-Coasian argument. As discussed by Dowd (1992), among others, one difficulty is that the Diamond-Dybvig model assumes that depositors are residual claimants rather than being entitled to fixed payment promises and consequently seems more attuned to mutual funds than to depository institutions such as commercial banks. Second, Dowd (2000) argues that a market for privately contracted deposit insurance could substitute for government involvement, which suggests that a Coasian solution to

meltdowns. 
the Diamond-Dybvig problem may exist after all. The third difficulty, also noted by Dowd (1992), is that Diamond and Dybvig's proposed central-planning-style solution involving a single guarantor essentially pushes the externality outside of the private marketplace and into the realm of taxpayers. Hence, a government-based solution does not actually eliminate the externality but instead requires effort by a government guarantor to internalize the externality in some other way, such as through the creation of a regulatory superstructure aimed at preventing systemic risks and providing macroprudential supervision.

Nevertheless, one can argue on Coasian grounds that establishment of a macroprudential-supervision regime likely will undermine the ability to obtain private solutions to any systemic-risk-based externalities. As noted previously, to the extent that macroprudential regulators are subject to industry capture, one outcome of establishing a system of macroprudential supervision will be reduced industry competition. In addition, heavy reliance on the capital-requirements pillar of the Basel II and III regulatory superstructures instead of on market discipline tends to undermine the importance of informational transparency - as do policies of banking and monetary authorities to withhold information about "liquidity assistance" or outright bailouts provided to individual institutions. In addition, a greater lack of clarity between private and public property rights inherent in broadened macroprudential supervision likely will hinder private agents' capabilities to resolve externalities by internalizing them via private contracts.

The overarching government failure during the 1990s and 2000s was - and continues to be-an attempted substitution of government 
oversight of markets for private market discipline. The government's safety-net system and the associated regulatory apparatus may well have been constructed in response to apprehensions about market externalities. Nevertheless, the design of that apparatus contributed to a significant breakdown in assignment of private property rights. As De Soto (2009) points out, the bulk of so-called "toxic assets" created by the mortgage-value meltdown were designated as such because of a failure - arising from adverse moral hazard incentives created by mispriced or unpriced deposit insurance and other government guarantees - of mortgage-backed securities and other related derivative securities to be carefully "recorded, continually tracked, and tied to the assets they represent." Finally, adding a macroprudential-supervision superstructure operating alongside the already complex layers of government regulation of financial institutions undoubtedly adds to the transaction costs that these institutions confront when negotiating private contracts.

Consequently, opting for expanding the scope of the overall financial regulatory superstructure in the form of macroprudential supervision arguably also constitutes a choice to reduce the scope for potential Coasian solutions to negative externality problems related to systemic risk. In an important sense, establishing macroprudential regulation likely forecloses opportunities for market participants to protect themselves from systemicrisk spillovers via private contracting. It is likely that the imposition of more government regulation crowds out self-regulation through the establishment of explicit contracts in private markets. Thus, expanding the regulatory superstructure via a new layer of macroprudential regulations could in fact add to the potential for systemic-risk-inducing externalities to arise in private markets. In short, government regulatory failures can 
contribute to the development of private market failures, yet this fact is rarely confronted in discussions of and writings on systemic risks and macroprudential regulation. ${ }^{17}$

\section{Conclusion}

The Financial Stability Oversight Council created by the Dodd-Frank Wall Street Reform and Consumer Protection Act has been charged with identifying and regulating systemically important institutions.

Consequently, Congress has set financial regulatory agencies on a path toward engaging in macroprudential regulation of systemic risk. This first step in the direction of establishing new layers of macroprudential regulation has been taken in spite of the fact that there is neither a single definition of the concept nor a generally agreed upon approach to measuring systemic risks. Furthermore, even though a number of academic economists and policymakers favor macroprudential regulation, there is not yet a clear consensus about how a system for containing systemic risks

${ }^{17}$ Consider, for instance, the Federal Reserve's efforts to address payment system risks relating to banks' daylight overdrafts. A key incentive to run daylight overdrafts was the fact that the Federal Reserve initially imposed no interest fee on overdrafts of deposit accounts with the Fed that banks initiated via interbank loans or book-entry security transactions transmitted via the Fed's Fedwire large-value payment system. Thus, the Fed effectively granted interest-free intraday loans to institutions utilizing that system; these daylight overdrafts exposed the Fed to credit risks on the system and more broadly exposed all large-value payment systems to systemic risks. After various experiments with institutional self-regulation, the Fed began charging an explicit interest fee on daylight overdrafts in the early 1990s. Although this explicit fee (which during the 2000s was replaced by an implicit opportunity cost of collateralized overdrafts) was always less than the estimated opportunity cost of intraday funds and hence failed to eliminate daylight overdrafts, the implementation of a positive fee noticeably reduced the scale of the overdraft problem. Separately, the Clearing House Interbank Payments System initially limited the scope of daylight overdrafts by restructuring its contractual agreements initially via centralized netting arrangements aimed at reducing gross risk exposures and later by moving toward real-time payment transmissions. Hence, systemic risks were initially generated in part by Fed policies (below-market intraday interest fees), whereas Coasian-style solutions emerged in the parallel private large-value payment system. 
should be implemented. Some researchers concur with the Dodd-Frank Act's emphasis on macroprudential-supervision efforts directed primarily toward large, "systemically important institutions." A few, however, worry that this focus leaves out other individually smaller institutions that nonetheless tend to engage in herding strategies that consequently might expose the banking system and financial markets to systemic risks. Others are concerned about the potential for bureaucratic inertia, monetary policy conflicts, and policy miscommunications to undercut the promise that they otherwise perceive in a macroprudential-supervision effort.

Furthermore, there are three deeper issues that have yet to be meaningfully addressed in evaluations of macroprudential regulation of systemic risks. One problem is that adding macroprudential supervisory policies to the layer of regulation already faced by financial institutions expands the points of contact between government supervisors and regulated institutions. The result is an enlarged potential for capture of the regulators by the large, systemically important firms that they are charged with supervising - to the detriment of both their competitors not judged systemically important and of consumers.

Another difficulty is that adding macroprudential regulation to an already substantial bank-regulation superstructure threatens to substitute to an even larger extent supervisory rules and discretionary policies in place of market discipline. In spite of demonstrated governmental and regulatory failures before and during the Panic of 2008, the presumption of most academic researchers and policymakers seems to be that private institutions are plagued by unavoidable market failures that can be addressed only through even more governmental regulatory and supervisory involvement.

Finally, a broadening of the scope of regulation is being pursued 
without accounting for the possibility that Coasian solutions might exist in financial markets in which transaction costs otherwise should be low and property rights otherwise should be well-defined and enforceable - as long as processes for generating transparent information are put into place. Unfortunately, substantial layers of both micro- and macroprudential regulations are likely to raise transaction costs faced by private financial institutions. In addition, the coupling of regulatory burdens with implicit bailout guarantees makes private property rights less certain. Furthermore, the continuing Basel II/III emphasis on capital regulation and governmental supervisory powers over the importance of clear market signals and market discipline undermine the informational transparency required for attainment Coasian solutions.

Even as initial steps are under way to enforce the Dodd-Frank Act's macroprudential-supervision requirements, there is a strong argument to be made that researchers should explore alternatives that rely less on government command and control mechanisms and more on private market discipline. Reforms in deposit insurance, government housing and consumer protection policies, financial regulatory governance, and informational transparency rules for both private and government actors would all be consistent with a shift away from central planning to marketoriented solutions to the systemic-risk problem. In the meantime, efforts to better understand the nature and sources of systemic risks and to measure these risks should continue. Whether such risks would be better addressed by government policymakers or private agents via Coasian contracts, the problem of systemic-risk definition and measurement still awaits final resolution. 


\section{REFERENCES}

Abrams, Burton, and Russell Settle, 1993, Pressure-group influence and institutional change: Branch-banking legislation during the Great Depression, Public Choice 77, 687-705.

Acharya, Viral, 2009, A theory of systemic risk and design of prudential bank regulation, Journal of Financial Stability 5, 224-255.

Acharya, Viral, John Biggs, Hanh Le, Matthew Richardson, and Stephen Ryan, eds., 2011, Systemic risk and the regulation of insurance companies in Regulating Wall Street: The Dodd-Frank Act and the New Architecture of Global Finance, New York, pp. 241-301.

Acharya, Viral, Lasse Pedersen, Thomas Phillippon, and Matthew Richardson, 2010, Measuring systemic risk, Manuscript, Stern School of Business, New York University, May.

Acharya, Viral, Lasse Pedersen, Thomas Phillippon, and Matthew Richardson, 2011c, in Viral Acharya and Matthew Richardson, eds., Regulating Wall Street: The Dodd-Frank Act and the New Architecture of Global Finance, New York: New York University, pp. 87-119.

Acharya, Viral, Lasse Pedersen, Thomas Philippon, and Matthew Richardson, 2011b, Regulating systemic risk, in Viral Acharya and Matthew Richardson, eds., Regulating Wall Street: The Dodd-Frank Act and the New Architecture of Global Finance, New York: New York University, pp. 288-303.

Acharya, Viral, Lasse Pedersen, Thomas Philippon, and Matthew Richardson, 2011a, Taxing systemic risk, in Viral Acharya and Matthew Richardson, eds., Regulating Wall Street: The Dodd-Frank Act and the New Architecture of Global Finance, New York University: New York, pp. 121-142.

Acharya, Viral, and Matthew Richardson, eds., 2010, Restoring Financial Stability: How to Repair a Failed System, New York: New York University. 
Acharya, Vira, and Tanju Yorulmazer, 2008, Information contagion and bank herding, Journal of Money, Credit, and Banking 50, 215-231.

Acharya, Vira, and Tanju Yorulmazer, 2007, Too many to fail-An analysis of time-inconsistency in bank closure policies, Journal of Financial Intermediation 16, 1-31.

Adrian, Tobias, and Markus Brunnermeier, 2009, CoVar, Federal Reserve Bank of New York Staff Report N. 348, Revised August.

Aikman, David, Piergiorgio Alessandri, Bruno Eklund, Prasanna Gai, Sujit Kapadia, Elizabeth Martin, Nada Mora, Gabriel Sterne, and Matthew Willison, 2009, Funding liquidity risk in a quantitative model of systemic stability, Bank of England Working Paper No. 372, June 2009.

Albertazzi, Ugo, and Leonardo Gambacorta, 2009, Bank profitability and the business cycle 5, 393-409.

Alexander, Kern, Rahul Dhumale, and John Eatwell, 2006, Global Governance of Financial Systems: The International Regulation of Systemic Risk, Oxford: Oxford University Press.

Bae, Kee-Hong, G. Andrew Karolyi, and René Stulz, 2003, A new approach to measuring financial contagion, Review of Financial Studies 16, 717763.

Bank of England, 2009, The role of macroprudential policy, Discussion Paper, 2009.

Barrell, Ray, E. Phillip Davis, Dilruba Karim, and Iana Liadze, 2010, Bank regulation, property prices, and early warning systems for banking crises in OECD countries, Journal of Banking and Finance 34, 22552264.

Bernanke, Ben, 2008, Reducing systemic risk, Speech, Federal Reserve Bank of Kansas City Jackson Hole Conference, August 22.

Billio, Monica, Mila Getmansky, Andrew Lo, and Loriana Pelizzon, 2010, 
Measuring systemic risk in the finance and insurance sectors, MIT

Bliss, Robert, and George Kaufman, 2006, Derivatives and systemic risk: Netting, collateral, and closeout, Journal of Financial Stability 2, 5570 .

Borak, Donna, and Cheyenne Hopkins, 2010, Regulatory council off to shaky start, American Banker, October 4.

Borio, Claudio, 2009, The macroprudential approach to regulation and supervision, Vox (http://voxeu.org), April 14.

Borio, Claudio, 2003, Towards a macroprudential framework for financial supervision and regulation? BIS Working Paper No. 128, Bank for International Settlements, February.

Born, Benjamin, Michael Ehrmann, and Marcel Fratzscher, 2010, Macroprudential policy and central bank communication, Center for Economic Policy Research Paper No. DP8094.

Boyer, Pierre, and Jorge Ponce, 2010, Central banks, regulatory capture, and financial regulation, Paolo Baffi Centre Research Paper No. 2010-83, December 1.

Brown, Stephen, Anthony Lynch, and Antti Petajisto, 2011, Hedge funds, mutual funds, and ETFs, in Viral Acharya and Matthew Richardson, eds., Regulating Wall Street: The Dodd-Frank Act and the New Architecture of Global Finance, New York University: New York, pp. 351-368.

Brownlees, Christian, and Robert Engle, 2010, Volatility, correlation, and tails for systemic risk measurement, Working Paper, New York University, July.

Brunnermeier, Markus, Andrew Crockett, Charles Goodhart, Avinash Persaud, and Hyun Shin, 2009, The Fundamental Principles of Financial Regulation, Geneva Reports on the World Economy, \#11, London: Center for Economic Policy Research.

Caballero, Ricardo, and Alp Simsek, 2009, Fire sales in a model of 
complexity, Working Paper, Massachusetts Institute of Technology, October 28.

Calomiris, Charles, 2010, The Great Depression and other 'contagious' events, in The Oxford Handbook of Banking, ed. Allen Berger, Philip Moyneux, and John Wilson, Oxford: Oxford University Press, pp. 693-710.

Castrén, Olli, and Ilja Kristian Kavonius, 2009, Balance sheet interlinkages and macro-financial risk analysis in the euro area, European Central Bank Working Paper No. 1124, December.

Chakravorti, Sujit, 2000, Analysis of systemic risk in multilateral net settlement systems, Journal of International Financial Markets, Institutions, and Money 10, 9-30.

Čihák, Martin, and Klaus Schaeck, 2010, How well do aggregate prudential ratios identify banking system problems? Journal of Financial Stability 6, 130-144.

Clement, Piet, 2010, The term 'macroprudential': Origins and evolution, BIS Quarterly Review, Bank for International Settlements, March, 59-67.

Coase, Ronald, 1960, The problem of social cost, Journal of Law and Economics 3, 1-44.

Cocco, João, Francisco Gomes, and Nuno Martins, 2009, Lending relationships in the interbank market, Journal of Financial Intermediation 18, 24-48.

Daniels, Joseph, and David VanHoose, 2005, International Monetary and Financial Economics, $3^{\text {rd }}$ Edition, Thomson/South-Western: Mason, Ohio.

Daníelsson, Jón, 2008, Blame the models, Journal of Financial Stability 4, 321328.

Davis, E. Phillip, and Dilruba Karim, 2009, Macroprudential regulationThe missing policy pillar, Euroframe Conference on Economic Policy Issues in the European Monetary Union, June 12. 
Davis, E. Phillip, and Dilruba Karim, 2008, Comparing early warning systems for banking crises, Journal of Financial Stability 4, 89-120.

De Bandt, Olivier, Philipp Hartmann, and José Luis Peydró, 2010, Systemic risk in banking, in The Oxford Handbook of Banking, ed. Allen Berger, Philip Moyneux, and John Wilson, Oxford: Oxford University Press, pp. 633-672.

De Jonghe, Olivier, 2010, Back to basics in banking? A micro-analysis of banking system stability, Journal of Financial Intermediation 19, 387417.

De Nicolo, Gianni, and Myron Kwast, 2002, Systemic risk and financial consolidation: Are they related? Journal of Banking and Finance 26, 861-880.

De Soto, Hernando, 2009, Toxic assets were hidden assets, Wall Street Journal, March 25.

de la Torre, Augusto, and Alain Ize, 2011, Containing systemic risk: Paradigm-based perspectives on regulatory reform, World Bank Policy Research Working Paper 5523, January.

Delis, Manthos, Kien Tran, and Efthymios Tsionas, 2009, Quantifying and explaining parameter heterogeneity in the capital regulation-bank risk nexus, Working Paper, University of Ioannina, University of Lethbridge, and Athens University of Economics and Business, November.

Dewatripont, Mathias, Jean-Charles Rochet, and Jean Tirole, 2010, Balancing the Banks: Global Lessons from the Financial Crisis, Oxford: Oxford University Press.

Diamond, Douglas, and Philip Dybvig, 1983, Bank runs, deposit insurance, and liquidity, Journal of Political Economy 91, 401-419.

Dowd, Kevin, 2000, Bank capital adequacy versus deposit insurance, Journal of Financial Services Research 17, 7-15. 
Dowd, Kevin, 1992, Models of banking instability: A partial review of the literature, Journal of Economic Surveys 6, 107-132.

Duffie, Darrell, 2010, How big banks fail, and what to do about it, Princeton: Princeton University Press.

Eisenbeis, Robert, 2010, The financial crisis: Misdiagnosis and reactionary responses, Atlantic Economic Journal 38, 283-294.

Eichberger, Jürgen, and Martin Summer, 2005, Bank capital, liquidity, and systemic risk, Journal of the European Economic Association 3, 547555.

Eisenberg, Larry, and Thomas Noe, 2001, Systemic risk in financial systems, Management Science 47, 236-249.

Elsinger, Helmut, Alfred Lehar, and Martin Summer, 2006a, Systemically important banks: An analysis for the European banking system, International Economics and Economic policy 3, 73-89.

Elsinger, Helmut, Alfred Lehar, and Martin Summer, 2006b, Risk assessment for banking systems, Management Science 52, 1301-1314.

Evans, Owen, Alfredo Leone, Mahinder Gill, Paul Hilbers, Winfrid Blaschke, Russell Krueger, Marina Moretti, Jun Nagayasu, Mark O'Brien, Joy ten Berge, and DeLisle Worrell, 2000, Macroprudential indicators of financial system soundness, Occasional Paper No. 192, International Monetary Fund, April.

Fecht, Falko, and Hans Peter Grüner, 2007, Financial integration and systemic risk, Unpublished Working Paper, Deutsche Bundesbank and University of Mannheim, January 22.

Feldman, Ron, and Gary Stern, 2010, The Squam Lake Report: Observations from two policy professionals, Journal of Monetary Economics 57, 903-912

Freixas, Xavier, Bruno Parigi, and Jean-Charles Rochet, 2000, Systemic risk, 
interbank relations, and liquidity provision by the central bank, Journal of Money, Credit, and Banking 32, 611-638.

French, Kenneth, Martin Baily, John Campbell, John Cochrane, Douglas Diamond, Darrell Duffie, Anil Kashyap, Frederic Mishkin, Raghuram Rajan, David Scharfstein, Robert Shiller, Hyun Song Shin, Matthew Slaughter, Jeremy Stein, and René Stulz, 2010, The Squam Lake Report: Fixing the Financial System, Princeton: Princeton University Press.

Furfine, Craig, 2003, Interbank exposures: Quantifying the risk of contagion, Journal of Money, Credit, and Banking 35, 111-128.

Gauthier, Céline, Alfred Lehar, and Moez Mouissi, 2010, Macroprudential capital requirements and systemic risk, Manuscript, Bank of Canada and University Calgary, July.

Gilbreath, Kent, 2008, The coming 'perfect economic storm,' Unpublished Working Paper, Baylor University, issued in installments beginning in early 2007.

Grace, Martin, 2010, The insurance industry and systemic risk: Evidence and discussion, Networks Financial Institute Policy Brief 2010-PB-02, April.

Group of 10, 2001, Consolidation in the Financial Sector, Bank for International Settlements, January.

Hakenes, Hendrik, and Isabel Schnabel, 2010a, Credit risk transfer and bank competition, Journal of Financial Intermediation 19, 308-332.

Hakenes, Hendrik, and Isabel Schnabel, 2010b, Banks without parachutes: Competitive effects of government bail-out policies, Journal of Financial Stability 6, 156-168.

Hanson, Samuel, Anil Kashyap, and Jeremy Stein, 2010, A macroprudential approach to financial regulation, Journal of Economic Perspectives, Forthcoming.

Hardy, Daniel, 2006, Regulatory capture in banking, International Monetary 
Fund Working Paper WP/06/34, January.

Hindriks, Jean, and Gareth Myers, 2006, Intermediate public economics, Cambridge, MA: MIT Press.

Hirtle, Beverly, Til Schuermann, and Kevin Stiroh, 2009, Macroprudential supervision of financial institutions: Evidence from the SCAP, Federal Reserve Bank of New York Staff Report No. 409, November.

Hopkins, Cheyenne, 2010, FSOC has many members, many more doubters, American Banker, December 30.

Hopkins, Cheyenne, and Donna Borak, 2011, Few trees to be found in a forest of FSOC reports, American Banker, January 19.

Horobin, William, and Nathalie Boschat, 2011, FSA may seek to block hostile U.K. bank buys, Wall Street Journal, January 7.

Huang, Xin, Hao Zhou, and Haibin Zhu, 2010, Systemic risk contributions, Working Paper, University of Oklahoma, Board of Governors of the Federal Reserve System, and Bank for International Settlements, August.

Huang, Xin, Hao Zhou, and Haibin Zhu, 2009, A framework for assessing the systemic risk of major financial institutions, Journal of Banking and Finance 33, 2036-3049.

Iori, Giulia, Saqib Jafarey, and Francisco Padilla, 2006, Systemic risk on the interbank market, Journal of Economic Behavior and Organization 61, 525-542.

Jokipii, Terhi, and Alistair Milne, Forthcoming, Bank capital buffer and risk adjustment decisions, Journal of Financial Stability.

Jones, Kenneth, and Robert Oshinksky, 2009, The effect of industry consolidation and deposit insurance reform on the resiliency of the U.S. bank insurance fund, Journal of Financial Stability 5, 57-88.

Jorion, Philippe, and Gaiyan Zhang, 2009, Credit contagion from 
counterparty risk, Journal of Finance 64, 2053-2087.

Kane, Edward, 2010a, Missing elements in U.S. financial reform: A KüblerRoss interpretation of the inadequacy of the Dodd-Frank Act, Working Paper, Boston College, August.

Kane, Edward, 2010b, Redefining and containing systemic risk, Atlantic Economic Journal 38, 251-264.

Kashyap, Anil, Richard Berner, and Charles Goodhart, 2010, The Macroprudential Toolkit, Chicago Booth Initiative on Global Markets Working Paper No. 60, December.

King, Michael, and Philipp Maier, 2009, Hedge funds and financial stability: Regulating prime brokers will mitigate systemic risk, Journal of Financial Stability 5, 283-297.

Kroszner, Randall, and William Melick, 2008, Lessons from the U.S. experience with deposit insurance, in Deposit Insurance Around the World: Issues of Design and Implementation, ed. Asli DemirgüçKunt, Edward Kane, and Luc Laeven, Cambridge, MA: MIT Press, pp. 181-217.

Kroszner, Randall, and Philip Strahan, 2001, Obstacles to optimal policy: The interplay of politics and economics in shaping bank supervision and regulatory reforms, In Frederic Mishkin (Ed.), Prudential Supervision: What Works and What Doesn't, Chicago, University of Chicago Press, pp. 233-272.

Kroszner, Randall, and Philip Strahan, 1999, What drives deregulation? Economics and politics of the relaxation of bank branching restrictions, Quarterly Journal of Economics 114, 1437-1467.

Kupiec, Paul, and David Nickerson, 2004, Assessing systemic risk exposure from banks and GSEs under alternative approaches to capital regulation, Journal of Real Estate Finance and Economics 28, 123-145.

Laffont, Jean-Jacques, and Jean Tirole, 1991, The politics of government decision-making: A theory of regulatory capture, Quarterly Journal 
of Economics 106, 1089-1127.

Lehar, Alfred, 2005, Measuring systemic risk: A risk management perspective, Journal of Banking and Finance 29, 2577-2603.

Levine, Ross, 2010 The governance of financial regulation: Reform lessons from the recent crisis, Bank for International Settlements Working Paper No. 329, November.

Lown, Cara, and John Wood, 2003, The determination of commercial bank reserve requirements, Review of Financial Economics 12, 83-98.

Mailath, George, and Loretta Mester, 1994, A positive analysis of bank closure, Journal of Financial Intermediation 3, 272-299.

Majnoni, Giovanni, 2010, The co-movement of asset returns and the micromacro focus of prudential oversight, World Bank Policy Research Working Paper No. 5456, October.

Masciandaro, Donato, and Marc Quintyn, 2008, Helping hand or grabbing hand? Politicians, supervision regime, financial structure and market view, North American Journal of Economics and Finance 19, 153-173.

Milne, Alistair, 2010, Using 'cap and trade' to contain systemic financial risk, Unpublished Manuscript, University of London, 2010.

Mishkin, Frederic, 2006, How big a problem is too big to fail? A review of Gary Stern and Ron Feldman's Too Big to Fail: The Hazards of Bank Bailouts. Journal of Economic Literature 44, 988-1004.

National Research Council, 2006, New Directions for Understanding Systemic Risk, Report on a conference cosponsored by the Federal Reserve Bank of New York and the National Academy of Sciences, May.

Perotti, Enrico, and Javier Suarez, 2009, Liquidity insurance for systemic crises, Policy Insight, Centre for Economic Policy Research, No. 31, February. 
Persaud, Avinash, 2009, Macro-prudential regulation, Crisis Response \#6, World Bank, July.

Phillips, Matt, 2010, Lehman's accidental historian, Wall Street Journal, September 18 .

Pollock, Alex, 2010, Why the Fed cannot regulate 'systemic risk,' The American, American Enterprise Institute, November 13.

Posner, Richard, 1974, Theories of economic regulation, Bell Journal of Economics and Management Science 5, 335-358.

Posner, Richard, 1971, Taxation by regulation, Bell Journal of Economics and Management Science 2, 22-50.

Rehm, Barbara, 2011, It's rubber-meets-the-road time for oversight council, American Banker, January 13.

Rochet, Jean-Charles, 2010, Systemic risk: Changing the regulatory perspective, International Journal of Central Banking 6, 259-276.

Rochet, Jean-Charles, and Jean Tirole, 2008, Competition policy in two-sided markets, with special emphasis on payment cards, in Paulo Buccirossi, ed. Handbook of Antitrust Economics, Cambridge, MA: MIT Press, pp. 543-582.

Rochet, Jean-Charles, and Jean Tirole, 2006, Two-sided markets: A progress report, Rand Journal of Economics 37, 645-667.

Rochet, Jean-Charles, and Jean Tirole, 1996, Interbank lending and systemic risk, Journal of Money, Credit, and Banking 28, 733-762.

Rosen, Harvey, and Ted Gayer, 2010, Public Finance, McGraw-Hill: New York, $9^{\text {th }}$ Edition.

Schotter, Andrew, and Tanju Yorulmazer, 2009, On the dynamics and severity of bank runs: An experimental study, Journal of Financial Intermediation 18, 217-241. 
Segoviano, Miguel, and Charles Goodhart, 2009, Banking stability measures, International Monetary Fund Working Paper WP/09/04, January.

Staum, Jeremy, 2010, Systemic risk components and deposit insurance premia, Working Paper, Northwestern University, December 14.

Stigler, George, 1971, The theory of economic regulation, Bell Journal of Economics and Management Science 2, 3-21.

Tarashev, Nikola, Claudio Borio, and Kostas Tsatsaronis, 2010, Attributing systemic risk to individual institutions, Bank for International Settlements Working Paper No. 308, May.

Thornton, Daniel, 2010, The effectiveness of unconventional monetary policy: The term auction facility, Working Paper 2010-044A, Federal Reserve Bank of St. Louis, October.

Upper, Christian, 2007, Using counterfactual simulations to assess the danger of contagion in interbank markets, BIS Working Paper No. 234, August.

VanHoose, David, 2011, Regulation of bank management compensation, in Financial Market Regulation: Legislation and Implications, ed. John Tatom, Springer, pp. 163-183.

VanHoose, David, 2009, Two-sided markets, bank card payment networks, and public policy, Networks Financial Institute Policy Brief No. 2009PB-01, Indianapolis, IN, January.

VanHoose, David, 2007a, Market discipline and supervisory discretion in banking: Reinforcing or conflicting pillars of Basel II? Journal of Applied Finance 17, 105-118.

VanHoose, David, 2007b, Theories of bank behavior under capital regulation, Journal of Banking and Finance 31, 3680-3697.

VanHoose, David, and Gordon Sellon, Jr., 1989, Daylight overdrafts, payments system risk, and public policy, Federal Reserve Bank of Kansas City Economic Review, September/October. 
Veljanovski, Cento, 2010, Economic approaches to regulation, In Robert Baldwin, Martin Cave, and Martin Lodge, eds., The Oxford Handbook of Regulation, Oxford: Oxford University Press.

Viscusi, W. Kip, Joseph Harrington, and John Vernon, 2005, Economics of Regulation and Antitrust, Cambridge, MA: MIT Press.

von Peter, Goetz, 2009, Asset prices and banking distress: A macroeconomic approach, Journal of Financial Stability 5, 298-319.

Wagner, Wolf, 2010, Diversification at financial institutions and systemic crises, Journal of Financial Intermediation 19, 373-386.

Wagner, Wolf, 2009, In the quest of systemic externalities: A review of the literature, Working Paper, Tilburg University, February.

Wagner, Wolf, 2008, The homogenization of the financial system and financial crises, Journal of Financial Intermediation, 17, 330-356.

Wagner, Wolf, and Ian Marsh, 2006, Credit risk transfer and financial sector stability, Journal of Financial Stability 2, 173-193.

Weinberg, John, 2002, Competition among bank regulators, Federal Reserve Bank of Richmond Quarterly 88, Fall, 19-36.

White, William, 2008, Past financial crises, the current financial turmoil, and the need for a new macrofinancial stability framework, Journal of Financial Stability 4, 307-312.

Wicker, Elmus, 1996, The Banking Panics of Great Depression, Cambridge, UK: Cambridge University Press.

Winston, Clifford, 2006, Government Failure versus Market Failure: Microeconomics Policy Research and Government Performance, Washington, DC: AEI-Brookings Joint Center for Regulatory Studies.

Wyplosz, Charles, 2009, The ICMB-CEPR Geneva Report: 'The Future of Financial Regulation,' Vox, January 27. 
(http://www.voxeu.org/index.php?q=node/2872).

Zhou, Chen, 2010, Are banks too big to fail? Measuring systemic importance of financial institutions, International Journal of Central Banking 6, 205-250. 